4. Hoàng Ngoc Minh (2020). "Nghiên cứu khả năng cố định ổ gãy trên thực nghiệm và kết quả điêu trị gãy kín đâuu dưới xướng đưi nìười lớn bằng nẹp khóa". Luận án Tiến sĩ y học, Học Viện Quân Y.

5. Martinet $O$, Cordey J, Harder Y, et al (2000). "The epidemiology of fractures of the distal femur". Injury, 31 Suppl 3, C62-63.

6. Chapman W.M. (1993). "Supracondylar and articular fractures of the distal femur". Operative orthopaedics, 1, $651-661$.

7. Coon M.S, Best B.J (2021). "Distal Femur Fractures". Treasure Island (FL): StatPearls Publishing.

8. Campana V, Ciolli G, Cazzato G, et al (2020). "Treatment of distal femur fractures with VA-LCP condylar plate: A single trauma centre experience". Injury, 51 Suppl 3, S39-S44.

\title{
VAI TRÒ CỦA ĐO ẢNH ĐộNG NHÃN Đồ (VNG) TRONG CHẨN ĐOÁN RỐI LOẠN TIỀN ĐÌNH
}

\author{
Lê Minh Kỳ*,**, Đồng Thị Như Quỳnh**, Trần Phương Thanh**, \\ Đoàn Việt Cường**, Dương Đình Lương**, Nguyễn Thị Tố Uyên***.
}

\section{TÓM TẮT}

Chóng mặt là một rối loạn thường gặp, bệnh nhân bị chóng măt có thế tới khám và điều tri ở các chuyên khoa khác nhau như nội thần kinh, lão khoa, nội khoa, tai mũi họng... Mỗi chuyên khoa lại có tiếp cận khác nhau trong chẩn đoán, xét nghiệm thăm dò thường làm nhất là chup CT và MRI sọ não. Tuy vậy đôi khi vẫn bỏ sót nhiểu chẩn đoán nguyên nhân. Hê thống VNG có thể ghi lại và lượng giá được hệ thổng vận đông nhãn câu và phản xa tiền đành mắt (VOR). Chúng tôi sử dụng bộ test đánh giá tiền đình gồm VNG và vHIT và thăm dò thính học để sàng lọc và phân loại nguyên nhân rối loạn tiền đình, chụp CT hoăc MRI so não nếu cần. Mục tiêu nghiên cứu nhằm phẩn loại các nguyên nhân gầy rối loạn tiền đình đến khám tại phòng khám TMH dựa trên bồ test đánh giá. Đối tượng và phương pháp nghiên cứu: 668 bệnh nhân đển khám vì chóng măt tai phòng khám TMH BV đa khoa Tâm Anh Hà Nội từ tháng 11/2018 đến tháng 7/2019. Tất cả bệnh nhân đều được khám lâm sàng, làm các nghiệm pháp tiền đình đơn giản và được đánh giá bằng bộ test trên hệ thống VNG, vHIT (Interacoustic), các thăm dò thính học như đo thính lực đơn âm, nhĩ lượng. Kết quả: Rối loạn tiền đình do nguyên nhân trung ương chiếm 55,9\%, chóng mặt do rối loạn tiền đình ngoại biên có chiếm $63,9 \%$. Trong số các nguyên nhân ngoai biên, BPPV (Bênh thach nhî lạc chỗ) chiếm nhiều nhất với tỷ lệ $66,5 \%$; Sau đó là Bênh Meniere chiếm 27,6\%; Viêm thần kinh tiền đình chiếm $22,2 \%$. Bệnh thạch nhĩ lạc chỗ ống bán khuyên sau chiếm đa số $83,5 \%$, ống bán khuyên ngang $26,8 \%$ và ống bán khuyên trước 14,8\%. Bệnh thạch nhî lac chố cả hai bên đồng thời chiếm 33,5\%. Kết luận: Bộ test thăm dò chức năng tiền đình VNG, vHIT, thắm dò thính học là một thăm dò cân thiết

*Đai hoc QG Hà Nọi (VNU)

**Bệnh viện Đa khoa Tâm Anh Hà Nội

***Đai hoc Y Hà Nôi

Chịu trách nhiệm chính: Lê Minh Kỳ

Email: leminhky.ent@gmail.com

Ngày nhận bài: 13.9.2021

Ngày phản biên khoa hoc: 8.11.2021

Ngày duyệt bài: 16.11.2021 trong chẩn đoán nguyên nhân rối loan thăng bằng chóng mặt, cung cấp các dữ liệu khách quan, tin cậy trong xác lấp chẩn đoán nguyên nhân.

Tư khóa: VNG, vHIT, thính lực đồ.

\section{SUMMARY}

\section{ROLE OF VNG - vHIT IN THE DIAGNOSTIC} OF VESTIBULAR DISORDER

Dizzy or vestibular disorder patients frequently present in neurology, geriatric, general medicine and ENT clinics... and individual specialties may develop a strategy for evaluating symptoms of disequilibrium in their own particular area of expertise, but may either overlook the many causes of dizziness arising in other systems. The aim of this study was to evaluate the role of VNG, VHHIT and audiological test as a useful tool in evaluating patients with vertigo, to confirm the level of lesion in a patient with vertigo, to differentiate between central and peripheral causes of vertigo and to identify the cause of peripheral vertigo. Patients and method: This is a prospective descriptive study on 668 patients with dizziness or vertigo consulted at ENT Depart, Tam Anh hospital Hanoi from 2018 Nov to 2019, Jul. All patients have been investigated by the battery test included VNG, vHIT and audiological test. Results: 668 patients were included in the analysis (259 men (38,8\%), 409 woman $(61,2 \%)$, the peak of age interval was $50-59$ years old. The most frequently diagnosed peripheral disorders diseases were: benign paroxysmal positional vertigo, Ménière syndrome and vestibular neuritis. In $83,5 \%$ of cases, mainly affected was the posterior semicircular canal, in $26,8 \%$ of the patients - the horizontal semicircular canal, 95 patients $(35,5 \%)$ having bilateral canals simultaneously involved. Conclusions: Testing of the vestibulo-ocular through videonystagmography and vHIT, tonal vocal audiometry are important for a positive diagnosis and etiological differentiation of vestibular syndromes.

Keywords; video Head Impulse Test (vHIT), videonystagmography, audiogramme.

\section{I. ĐẶT VẤN ĐỀ}

Chóng mặt khá phổ biến trong đời sống 
thường ngày và trong y học lâm sàng. Với những biểu hiện và diễn biến, chóng mặt có thể là một triệu chứng, một hội chứng hoặc một bệnh lý cũng như có thể xảy ra đối với mọi người, mọi lứa tuổi, ở mọi nơi.

Nhiều nguyên nhân khác nhau có thể gây ra chóng mặt cho nên có khi đó là biểu hiện duy nhất nhưng cũng có khi nằm trong một bệnh cảnh phức tap.

Bệnh nhẩn bị chóng mặt có thể tới khám và điều trị ở mọi cơ sở y tế, từ các phòng khám đa khoa tới các trung tâm chuyên khoa khác nhau như nội thần kinh, lão khoa, nội khoa, tai mũi họng...Mỗi chuyên khoa lại có tiếp cận khác nhau trong chẩn đoán, xét nghiệm thăm dò̀ thường làm nhất là chụp CT và MRI sọ não. Tuy vậy đồi khi vẫn bỏ sót nhiều chẩn đoán nguyên nhân.

Có thể nói chóng mặt vẫn luôn là một vấn đề thời sứ, một trong tâm trong thực hành y khoa về chẩn đoán và điều trí.

Hầu hết các tổn thương tiền đình ngoại biên cũng như trung ương đều có liên quan đến các vận động bất thường của mắt, vì vậy để đánh giá sự toàn vẹn của hệ thống tiền đình ngoại biên, các nhà lâm sàng cân phải ghi lại chi tiểt các dạng vận động khác nhau của mắt để đánh giá, bởi vì rất khó để có các thăm dò trực tiếp vào các cơ quan tiền đình. Bên cạnh đó khám vận động của mắt cũng giúp các nhà lâm sàng đánh giá được các cơ quan, thần kinh phụ trách thăng bằng nằm ở tiểu não, thân não qua sự kết nối với thần kinh trung ương.

Hệ thống ENG và VNG hiện nay có thể ghi lại và lượng giá được hệ thống vận động nhãn câuu và phản xạ tiền đình mắt VOR.

Chúng tôi sử dụng bộ test đánh giá tiền đình gồm VNG và vHIT để sàng lọc và phân loại nguyên nhân rối loạn tiền đình, chụp CT hoặc MRI so não nếu cần.

Mục tiêu nghiên cứu nhằm phân loại các nguyển nhân gây rối loạn tiền đình đến khám tại phòng khám TMH dựa trên bộ test đánh giá.

II. ĐỐI TƯợNG VÀ PHƯƠNG PHÁP NGHIÊN CứU

668 bệnh nhân đến khám vì chóng mặt tại Phòng khám TMH BV đa khoa Tâm Anh Hà Nội từ tháng 11/2018 đến tháng 7/2019.

Tất cả bệnh nhân đều được khám lâm sàng, làm các nghiệm pháp tiền đình đơn giản và được đánh giá bằng bộ test trên hệ thống VNG, vHIT (Interacoustic), các thăm dò thính học như đo thính lực đợn âm, nhĩ lượng.

Về cơ bản trên các hệ thống VNG sẽ ghi lại và lượng hóa các vận động nhãn cầu trên các biểu đồ, trục đứng là cường độ vận động nhãn cầu, trục ngang là tần số xuất hiện.

Ví dụ biểu đồ trên là vận động của mắt trái, đường biểu diễn đi lên trên có nghĩa mắt trái chạy sang phải, xuống dưới nghĩa là mắt trái chạy sang trái, đường thẳng đứng nghĩa là mắt di chuyển theo trục đứng (vertical), đường nằm ngang là mắt di chuyển theo trục ngang (horizontal).

Nếu có ĐM xuất hiện, đường biểu diễn sẽ gập góc với 2 pha chậm và pha nhanh, máy sẽ ghi nhận có ĐM, bảng lượng giá sẽ cho ta biết có bao nhiêu động mắt ngang và bao nhiêu động mắt đứng.

\section{Goggles}
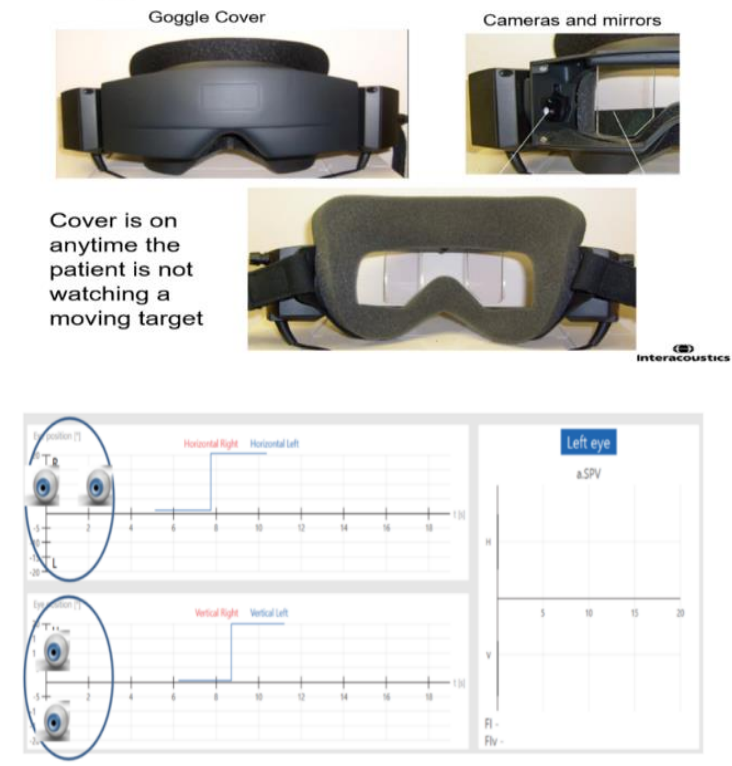

Bộ test Tiền đình bao gồm 7 nghiêm pháp:

1. Test Gaze stability. Mục đích nhằm đánh giá khả năng của bệnh nhân duy trì nhìn tập trung mắt vào một vật mà mắt không bị di chuyển do nguyên nhần bển ngoài (ví dụ như bị động mắt).

2. Test Smooth Pursuit. Mục đích nhằm đánh giá khả năng bệnh nhân bám mắt vào một vật di chuyển mềm mại, có kiểm soát.

3. Test Saccade. Mục đích nhằm đánh giá khả năng của bệnh nhân di chuyển mắt từ một điểm đã xác định sang một điểm khác với chuyển động đơn thuần và nhanh.

4. Test Optokinetic. Mục đích nhằm đánh giá khả năng bênh nhân theo dõi các vật di chuyển trong khi đầu vẫn giữ nguyên.

5. Các test tư thế như Dix-hallpike, Roll test

6.Test nhiệt lượng (Caloric test): Đánh giá chức năng tiền đình ngoại biên từng bên. 
7.vHIT: đánh giá có tổn thương của từng ống bán khuyên

Các số liệu thu thập được và phân tích, kết hợp với triệu chứng lâm sàng, đưa ra chẩn đoán dựa trên Phân loại quốc tế các rối loạn tiền đình của Hiệp hội Barany.[2]

\section{KẾT QUẢ NGHIÊN CỨU}

\section{Tuổi và giới tính}

Bảng 1. Phân bố nhóm tuổi và giới tính của đôî́ tượng nghiên cứu

\begin{tabular}{|c|c|c|c|}
\hline Đặc điểm & n & $\%$ & \multirow[b]{2}{*}{$\mathbf{p}$} \\
\hline Giới & & & \\
\hline Nũ̃ & 409 & 61,2 & \multirow{2}{*}{0,0001} \\
\hline $\mathrm{Nam}$ & 259 & 38,8 & \\
\hline Tuối & & & \\
\hline Dưới 30 & 23 & 3,4 & \multirow{6}{*}{0,0001} \\
\hline Từ $30-39$ & 92 & 13,8 & \\
\hline Từ $40-49$ & 165 & 24,7 & \\
\hline Từ 50-59 & 202 & 30,2 & \\
\hline Từ $60-69$ & 152 & 22,8 & \\
\hline Từ 70 trở lên & 34 & 5,1 & \\
\hline Tống & 668 & 100 & \\
\hline
\end{tabular}

Nhận xét. Trong số 668 bệnh nhân, nữ có 409 trường hợp, chiếm đa số $61,2 \%$. Tuổi thường gặp gặp nhất từ 50 đến 59 chiếm $30,2 \%$ các trường hợp đến khám, tiếp đến tuổi từ 40 đến 49 chiếm 24,7\%. Nhóm tuổi dưởi 30 ít gặp nhất chỉ chiếm 3,4\% trường hợp đến khám. Phân bố giới tính và nhóm tuổi là không đồng đều và sự khác biệt có ý nghĩa thống kê $(p<0,05$, Chi-Square test).

\section{Nguyên nhân}

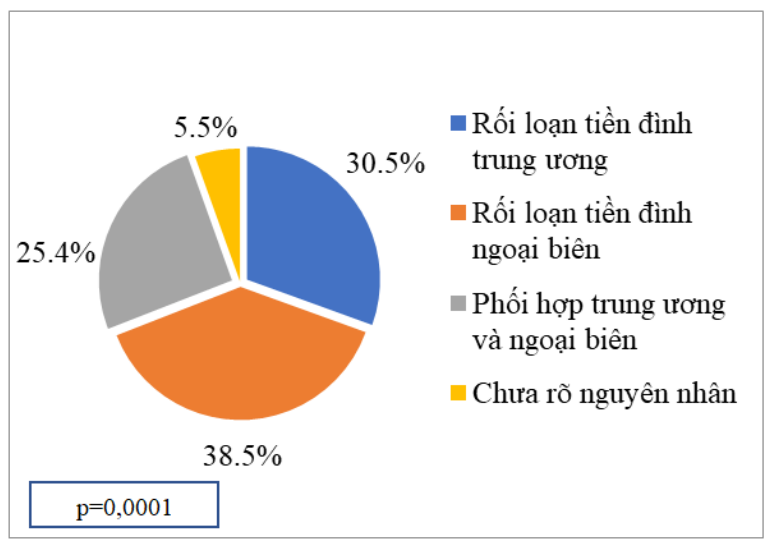

\section{Biểu đồ 1. Phân loại nguyên nhân gây chóng mặt}

Nhận xét: Rối loạn tiền đình do nguyên nhân trung ương chiếm 30,5\%, trong khi đó rối loạn tiền đình ngoại biên chiếm 38,5\%, nguyên nhân phối hợp chiếm 25,4\%. Có 5,5\% bệnh nhân chóng mặt chưa rõ nguyên nhân. Có sự khác biệt có ý nghĩa thống kê về nguyên nhân gây chóng mặt ( $p<0,05$, Chi-Square test).

\section{Nguyên nhân ngoại biên}

Bảng 2. Phân bố nguyên nhân gây rôí loạn tiền đình ngoại biên $(n=427)$

\begin{tabular}{|c|c|c|c|}
\hline $\begin{array}{c}\text { Nguyên nhân RLTĐ ngoại } \\
\text { biên }\end{array}$ & n & $\%$ & $\mathbf{p}$ \\
\hline Bênh thach nhĩ lac chô & 284 & 66,5 & \multirow{6}{*}{$\begin{array}{l}0,0 \\
001\end{array}$} \\
\hline Bệnh Meniere & 118 & 27,6 & \\
\hline Viêm thần kinh tiền đình & 95 & 22,2 & \\
\hline Bệnh viêm mê nhĩ & 13 & 3,0 & \\
\hline Yếu tiền đình hai bên & 12 & 2,8 & \\
\hline Xung đôt thần kinh mach máu & 4 & 0,9 & \\
\hline
\end{tabular}

Nhận xét: Trong 427 bệnh nhân có rối loạn tiền đình ngoai biên, BPPV chiếm nhiều nhất với 284 bệnh nhẩn, chiếm tỷ lệ $66,5 \%$, sau đó là Bệnh Meniere với 118 bệnh nhân chiếm 27,6\%, viềm thần kinh tiền đình 95 BN chiếm $22,2 \%$. Có sự khác biệt về nguyên nhân gây rối loạn tiền đình ngoại biên, sự khác biệt này có ý nghĩa thống kê ( $p<0,05$, Cochran's Q-test).

\section{Vị trí Thach nhĩ lac chố}

Bảng 3. Vị trí thạch nhĩ xét theo các ông bán khuyên $(n=284)$

\begin{tabular}{|c|c|c|c|}
\hline Ông bán khuyên & $\mathbf{n}$ & $\mathbf{\%}$ & \multirow{1}{*}{$\mathbf{P}$} \\
\hline Có RL ống BK sau & 237 & 83,5 & \multirow{1}{*}{0} \\
\hline Có TL ống BK ngang & 76 & 26,8 & \multirow{2}{*}{0,0001} \\
\hline Có RL ống BK trước & 42 & 14,8 & \\
\hline
\end{tabular}

Nhận xét: Bệnh thạch nhĩ lạc chố ống bán khuyên sau chiếm đa số với tỳ lệ $83,5 \%$, ống bán khuyên ngang chiếm $26,8 \%$ và ống bán khuyên trước chiếm 14,8\%.

Có sự khác biệt về thạch nhĩ theo vị trí ống bán khuyên rối loạn, sự khác biệt này có ý nghĩa thống kê ( $p<0,05$, Cochran's Q-test).

Bảng 4. Vị trí thạch nhĩ theo từng bên tai $(n=284)$

\begin{tabular}{|c|c|c|c|}
\hline Vị trí tai tốn thương & $\mathbf{n}$ & $\mathbf{\%}$ & \multirow{2}{*}{$\mathbf{p}$} \\
\hline Có RLTÐ tai phải & 185 & 65,5 & \\
\hline Có RLTÐ tai trái & 194 & 68,3 & \multirow{2}{*}{0,0001} \\
\hline Có RL cả hai bên & 95 & 33,5 & \\
\hline
\end{tabular}

Nhận xét: Có 185 bệnh nhân bị BPPV tai bên phải chiếm $65,5 \%$, có 194 bệnh nhần bị BPPV tai bên trái chiếm $68,3 \%$ và 95 bệnh nhân bị BPPV đồng thời cả hai bên tai, chiếm tỷ lệ 33,5\%. Có sự khác biệt về thạch nhĩ theo vị trí tai rối loạn, sự khác biệt này có ý nghĩa thống kê $(p<0,05$, Cochran's Q-test).

\section{BÀN LUẬN}

Trong nghiên cứu của chúng tôi, bệnh nhân đến khám vì chóng mặt, rối loạn thăng bằng đa số là bệnh nhân nữ chiếm $61,2 \%$, tuổi thường 
gặp gặp nhất từ 50 đến 59 chiếm 30,2\%.

Một nghiên cứu của Neuhauser HK và CS. (2005) qua điều tra trên 30.000 người ở Châu Âu cho thấy tần suất của chóng mă̆t tính theo tuổi là từ $17 \%$ lên tới $39 \%$ ở người trên 80 tuổi.[4].

Trên một nghiên cứu thăm dò về thần kinh của Brevern cho thây 243 trên 1003 người (24\%) bị chóng mặ̆t hay mất thăng bằng trung bình và nặng, có tiền sử bị chóng mă̆t, có đến 80 bệnh nhân $(8 \%)$ có đầy đủ tiêu chuẩn chấn đoán BPPV (gồm 56 nữ, 24 nam, độ tuổi từ 28-82). [1]

Panduranga trong 1 nghiên cứu trên $120 \mathrm{BN}$ đến khám ở trung tâm do bị chóng mặt trong vòng 24 tháng, có 56 nữ và 64 nam.[6]

Nhìn chung đa số các nghiên cứu cho thây tỷ lệ bênh nhân nữ đến khám vì chóng mặt cao hơn nam giới, với tuổi $60-80$ tuổi. Có thể thây đây là một bệnh lý liên quan nhiều đến người cao tuổi, có lẽ bệnh liên quan đến tình trạng thoái hóa các cơ quan tiền đình bao gồm cả thần kinh trung ương và ngoại biên.

Về nguyên nhân chúng tôi nhân thấy nguyên nhân ngoại biên chiếm chủ yểu đến $63,9 \%$, trong khi nguyên nhân trung ương chiếm $55,9 \%$. Tuy nhiên cần lưu ý có đến $25,4 \%$ có phối hợp cả ngoại biên và trung ương.

Cũng trong nghiên cứu của Paduranga trong $120 \mathrm{BN}$ có $50 \%$ có bất thường trên VNG, trong đó $39 \mathrm{BN}(33 \%)$ có tổn thương tiền đình ngọai biên và $21 \mathrm{BN}(18 \%)$ có tổn thương tiên đình trung ương.[6]

Có thể thấy rằng vai trò của nhóm làm việc trong việc thăm khám tiền đình là quan trọng, trong đó bao gồm bác sĩ chuyên khoa $T M H$, nội thần kinh, tâm thần, tâm lý ... bởi sự đan xen nhau của bệnh lý gây nên rối loạn tiền đình, một bệnh nhân có thể có nguyên nhân tiền đình trung ương đi kèm với một bệnh lý ngoại biên khác như Meniere hoặc BPPV.

Trong số các nguyên nhân ngoại biên, bệnh lý BPPV chiếm tỷ lệ cao nhất và chủ yếu với $66,5 \%$, cho thây sự phổ biến của bệnh lý này, thật vậy ngày ngay cơ chế bênh sinh ngày của bệnh càng được hiểu biết rõ ràng hơn, cho thây sự thoái hóa tai trong có thể là do lão hóa, do thiếu canxi... là một trong các nguyên nhân chủ yếu gây thiểu dưỡng các cơ quan thạch nhĩ làm thạch nhĩ dễ rời khỏi vị trí để rơi vào các ống bán khuyên.

Các nguyên nhân tiên đình ngoại biên khác thường gặp trong nghiên cứu của chúng tôi là bệnh Meniere $27,6 \%$ và viêm thần kinh tiên đình $22,2 \%$. Số liệu này cũng phù hợp với nghiên cứu của Loreta cho thấy 3 nguyên nhân thường gặp nhất của rối loạn tiền đình ngoại biên là BPPV, Meniere và viêm thần kinh tiền đình [ 3]. Qua số liệu này cho thây tỷ lệ bệnh Meniere khá cao, tuy nhiên việc khám chẩn đoán còn chưa đầy đủ, có thể bị bỏ sót trong chẩn đoán các rối loạn tiền đình.

Trong số các ống bán khuyên có thạch nhĩ lạc chỗ, ống bán khuyên sau chiếm tỷ lệ cao nhẩt, có nhiều cách lý giải khác nhau, tuy nhiên đa sô các tác giả đều thống nhất là do vị trí giải phẫu của của ống bán khuyên sau, sẽ nằm thấp nhất khi người bệnh nằm ngủ, đây là tư thế để thạch nhĩ dề rơi vào ống bán khuyên sau nhất, sau đó đến ống bán khuyên ngang, ống bán khuyên trước nằm cao nhất nên có lẽ như vậy ít gặp hơn. Có điểm lưu ý là trong nghiên cứu của chúng tôi có đến $33,5 \%$ có thạch nhĩ lạc chỗ cả 2 bên cùng một lúc.

Loreta trong nghiên cứu trên $87 \mathrm{BN}$, có $35 \mathrm{BN}$ có chẩn đoán BPPV. $88 \%$ trường hợp ở vị trí ống bán khuyên sau, $9 \%$ trường hợp ở ống bán khuyên ngang, 3\% bị cả 2 bên cùng một lúc [3].

\section{KẾT LUẬN}

Bộ test thăm dò chức năng tiền đình VNG, vHIT là một thăm dò cần thiết trong chẩn đoán nguyên nhân rối loạn thăng bằng chóng mặt, cung cấp các dữ liệu khách quan, tin cậy trong xác lập chẩn đoán nguyên nhân.

Nguyên nhân tiền đình ngoại biên chiếm đa sô $63,9 \%$.

Bệnh thạch nhĩ lạc chỗ là nguyên nhân chủ yếu gây rối loạn tiền đình ngoại biên.

\section{TÀI LIẸU THAM KHẢO}

1. Brevern $M$ von, Radtke $A$, Lezius $F$, Feldmann $M$, Ziese $T$, Lempert $T$, Neuhauser $H$. Epidemiology of benign paroxysmal positional vertigo: a population based study. J Neurol Neurosurg Psychiatry 2007;78:710-715. doi: 10.1136/jnnp.2006.100420.

2. International Classification of Vestibular Disorders (ICVD). Journal of Vestibular Research, Volume 31 (2021)

3. Loreta Ungureanu, S. Cozma, Luminiţa Rădulescu, D. Mârţu. Contribution of the audiological and vestibular assessment to the differential and etiological diagnosis of peripheric vestibular syndromes International Journal of Medical Dentistry. volume 2 - issue 3 July/ September 2012 • pp. 150-155

4. Neuhauser HK et al. Neurology 2005; 65: 898 - 904 (ref. from International Medical News 2007; 3:1).

5. Jaroslaw Milonski, Piotr Pietkiewicz, Marzena Bielinska, Krzysztof Kusmierczyk, Jurek Olszewski. The use of videonystagmography head impulse test (vhit) in the diagnostics of semicircular canal injuries in patients with vertigo. International 
Journal of Occupational Medicine and Environmental Health 2014; 27(4):583 - 590

6. Panduranga Kamath $M$, Vijendra Shenoy $S$, Suja Sreedharan, Kiran Bhojwani, Sujith Sam Mammen, Nazeem Abdul Majeed. Role of electronystagmography in balance disorders: A clinical study Indian Journal of Otology | July 2015

\section{| Vol 21 | Issue 3 |}

7. Simon.I.Angeli,

Sandra.Velandia,

Hillary.Snapp. Head-shaking nystagmus predicts greater disability in unilateral peripheral vestibulopathy American Journal of Otolaryngology-Head and Neck Medicine and Surgery 32(2011)522-527

\title{
NHIỄM HPV NGUY Cơ CAO TRÊN BÊNNH NHÂN CÓ TẾ BÀO ÂM ĐẠO CỔ TỬ CUNG BẤT THƯỜNG TẠI BỆNH VIÊ̂N PHỤ SẢN TRUNG ƯỚNG
}

\author{
Ngô Thị Thanh Hương ${ }^{1}$, Đào Thị Hoa ${ }^{2}$, Lê Hoàng ${ }^{3}$
}

\section{TÓM TẮT}

Mục tiêu: Xác định tỷ lệ nhiễm HPV nguy cơ cao trên bệnh nhân có tế bào âm đạo cổ tử cung bất thường và đối chiếu giữa kết quả HPV nguy cơ cao với kết quả tế bào âm đạo cổ tử cung bất thường. Đối tượng và phương pháp nghiên cứu: Nghiên cứu trên 259 phụ nữ đến khám tại khoa khám bệnh bệnh viện phụ sản Trung ương có xét nghiệm HPV nguy cơ cao và kết quả tế bào âm đạo CTC bất thường trong thời gian từ tháng 8/ 2020 đến tháng 4/ 2021. Kết quả nghiên cứu: Tuổi trung bình của phư nữ làm xét nghiệm là $38 \pm 9,1$; số phụ nữ trong độ tuổi từ 25 - 39 chiếm $52,9 \%$. Có $76,4 \%$ trường hợp bị nhiễm HPV trong đó: $37,1 \%$ nhiếm 1/12 Typ nquy cơ cao khác chiếm tỷ lệ cao nhất; $17,8 \%$ nhiễm Typ 16; 6,2\% nhiếm Typ 18; 15,4\% nhiếm từ 2 typ trở lên. Tỳ lệ tế bào âm đạo cổ tứ cung bất thường: $0,8 \%$ là ung thư tế bào vảy; $42,9 \%$ có tổn thương LSIL chiếm tỷ lê cao nhất; $18,5 \%$ là HSIL; $34,4 \%$ là tế bào phản ứng (ASC: $30,5 \%$ và AGC: $3,9 \%$ ). Có $69,6 \%$ tế bào ASCUS bi nhiễm HPV; $85,6 \%$ tế bào LSIL nhiễm HPV; $81,3 \%$ HSIL có nhiễm HPV và cả 2 trường hợp ung thư biểu mô vảy đều không nhiễm HPV.

Tưr khóa: Ung thư cổ tử cung, sàng lọc tế bào học phụ khoa, HPV

\section{SUMMARY \\ HIGH- RISK HPV INFECTION IN PATIENTS WITH ABNORMAL CERVICAL VAGINAL CELLS AT THE NATIONAL HOSPITAL OF OBSTETRICS AND GYNECOLOGY}

Objective: Determine the prevalence of high-risk $\mathrm{HPV}$ infection in patients with abnormal cervical vaginal cells and compare high- risk HPV results with abnormal cervical vaginal cytology results. Material and Methodology: Study on 259 women who visited the examination department at the National Hospital of Obstetrics and Gynecology with high- risk HPV test and

${ }^{1}$ Bệnh viện Sản Nhi Bắc Ninh

${ }^{2}$ Bệnh viện Phụ Sản Trung ương

${ }^{3}$ Bềnh viên Đa khoa Tâm Anh

Chịu trách nhiệm chính: Ngô Thị Thanh Hương

Email: ntthuong1607@gmail.com

Ngày nhận bài: 16.9.2021

Ngày phản biên khoa hoc: 11.11.2021

Ngày duyệt bài: 13.11.2021 abnormal cervical cell results during the period from $8 /$ 2020 to 4/2021. Result: The average age of women talking the test was $38 \pm 9,1$; the highest number of women aged $25-39$ accounted for $52,9 \%$. There were $76,4 \%$ cases of HPV infection in which: $37,1 \%$ infected with $1 / 12$ other high-risk types accounted for the highest rate; $17,8 \%$ infected with Type 16; 6,2\% infected with Type $18 ; 15,4 \%$ infected with 2 or more types. The percentage of abnormal cervical cells: $0,8 \%$ is squamous cell carcinoma; $42,9 \%$ had the highest percentage of LSIL lesions; $18,5 \%$ is HSIL; $34,4 \%$ were reactive cells (ASC: $30,5 \%$ and AGC: 3,9\%). There were $69,6 \%$ ASCUS cells infected with HPV; $85,6 \%$ of LSIL cells infected with HPV; $83,1 \%$ of HSIL had HPV infection and both squamous cell carcinoma cases were not infected with HPV.

Key words: Cervical cancer, gynecological cytology screening, HPV.

\section{I. ĐĂT VẤN ĐỀ}

Ung thư cổ tử cung ( UTCTC) là loại ung thư phổ biến, đứng thứ tư trong các loại ung thư ở nữ và thứ hai trong các loai ung thư phu khoa ${ }^{1,2}$. Nhiễm một hay nhiêu typ HPV nguy cơ cao là nguyên nhân gây ra sự biến đổi tế bào, trải qua giai đoạn tiên ung thư và dẫn đến UTCTC ${ }^{1}$. Quá trình tiến triển từ khi nhiễm HPV từ giai đoạn tiên ung thư đến UTCTC thường kéo dài từ 5 20 năm³ ${ }^{3}$ Ở Việt Nam đã có rất nhiều nghiên cứu về nhiễm HPV trong cộng đồng nhưng chưa có nhiều nghiên cứu về nhiễm HPV trên nhóm bệnh nhân làm xét nghiêm tế bào âm đạo. Nhằm xác định tỷ lệ nhiễm HPV ở các bệnh nhân có tế bào âm đạo cổ tử cung bất thường, chúng tôi tiến hành nghiên cứu này nhằm mục tiêu:" Xác định tỷ lệ nhiễm HPV nguy cơ cao trên bệnh nhân có tế bào âm đạo cổ tử cung bất thường và đối chiếu giữa kêt quả HPV nguy cơ cao với kết quả tế bào âm đạo cổ tử cung bất thường".

\section{II. ĐỐI TƯỢNG VÀ PHƯƠNG PHÁP NGHIÊN CỨU}

2.1. Đối tượng nghiên cứu: Phụ nữ đến khám bệnh tại Bệnh viện Phụ sản Trung ương phù hợp với tiêu chuẩn lựa chọn, tiêu chuẩn loại 